
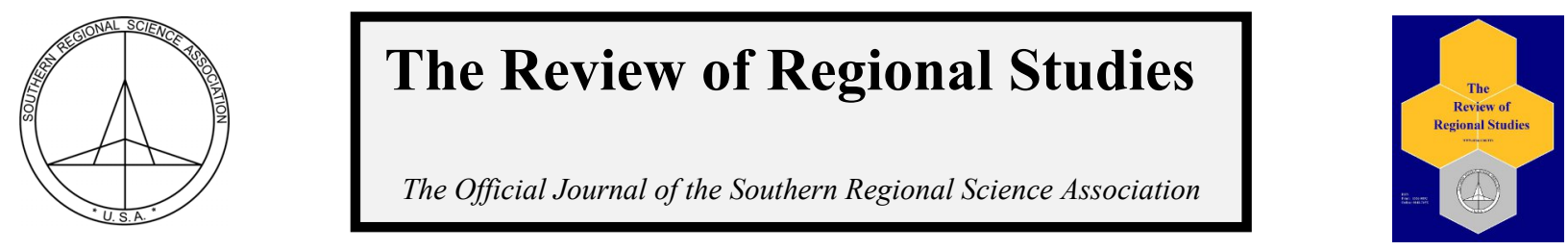

Presidential Address-Arlington, Virginia, April 6, 2013

$52^{\text {nd }}$ Meetings of the Southern Regional Science Association:

\title{
Should Oklahoma Be More Like Texas? A Taxing Decision
}

\author{
Dan S. Rickman
}

Department of Economics and Legal Studies in Business, Oklahoma State University, USA

\begin{abstract}
In his Presidential Address, Professor Rickman discusses whether Texas should serve as the economic policy model for Oklahoma, particularly in terms of reducing or eliminating the state income tax. He compares Oklahoma's recent economic performance to that of Texas and other adjacent states. Comparisons are made at both the state and county levels, for different time periods, and for several economic indicators. County-level regression analysis, of all counties, and separately for only border counties, both explicitly and implicitly controls for potential nonpolicy growth influences. He concludes that there is not sufficient evidence to warrant Oklahoma emulating Texas' economic policies.
\end{abstract}

Keywords: state income tax, Oklahoma, Texas

JEL Codes: R51, R58, H30

\section{INTRODUCTION}

Although long debated, the issue of whether state income taxation affects economic growth heated up in 2012 as a number of states considered repealing or reducing their personal income tax rates (Wall Street Journal, 2012b). In Oklahoma, Republican Governor Mary Fallin proposed lowering the top state personal income tax rate from 5.25 percent to 3.5 percent as part of a long-run strategy to eliminate the state income tax, with proposed revenue offsets to be obtained by eliminating numerous state tax credits (Wall Street Journal, 2012a). Despite significant Republican majorities in the legislature, the measure failed. Intense lobbying by special interest groups preserved the tax credits proposed for elimination, and tax burdens would have increased for some Oklahomans. The proposed increased tax burdens could have been interpreted as violating the state constitutional requirement of three-fourths approval in the House and Senate for enactment of tax increases (Wertz, 2012).

Oklahoma experienced the third largest drop in per pupil spending during Fiscal Years 2008-2013 (Oliff et al., 2012). According to the Tax Foundation (2013), Oklahoma had only the $36^{\text {th }}$ highest state and local tax burden as a share of income in Fiscal Year 2010. Correspondingly, compared to the nation, Oklahoma raised lower shares of state and local tax revenue from the personal income tax, corporate income tax and property tax, while it was in the top ten states in terms of the sales tax share (Tax Foundation, 2013). Yet, early in the 2013 legislative session, the Oklahoma Senate passed legislation reducing the top rate from 5.25 to

Rickman is Regents Professor of Economics and Oklahoma Gas and Electric Services Chair in Regional Economic Analysis at Oklahoma State University, Stillwater, OK 74078, USA. E-mail: dan.rickman@,okstate.edu

C) Southern Regional Science Association 2013.

ISSN 1553-0892, 0048-749X (online)

www.srsa.org/rrs 
4.75 percent, offsetting revenue losses by reducing tax credits, while bills were sponsored in the House that would reduce the rate from 5.25 to 5 percent, without any offsets in revenue (Murphy, 2013).

Just to the north of Oklahoma, Kansas reduced the top personal income tax rate from 6.45 percent to 4.9 percent in 2012 and eliminated the tax for approximately 190,000 small businesses (without broadening the base), which was followed by a proposal in 2013 to further reduce the rate to 3.5 percent with offsetting revenue to be obtained by raising the state sales tax (Malm and Henchman, 2013; Morris, 2013). Kansas Governor Brownback acknowledged that the reduction of the income tax rate contributed to subsequent projected budget shortfalls (Hanna, 2013; Shields, 2012). Similar proposals were introduced in other states with significant Republican influence-Indiana, Louisiana, Nebraska, North Carolina and Ohio (King and Peters, 2013).

Texas is typically viewed as the model of economic success for states considering eliminating or reducing their state income tax (Wall Street Journal, 2012b; Jones, 2013). Oklahoma, in particular, routinely measures itself against Texas (McGuigan, 2013). In her State of the State Address in 2012, Oklahoma Governor Fallin indicated that under her proposal to reduce income taxes, Oklahoma would have the lowest state personal income tax in the region outside of Texas and that Oklahoma eventually should be like Texas in having no income tax. Likewise, when making a similar proposal, Kansas Governor Brownback stated that "...the goal is for our economy to look more like Texas, and a lot less like California" (Wall Street Journal, 2012b). The Texas experience also was a cornerstone of Texas Governor Rick Perry's bid for the presidency and routinely arises in debates over state economic performance (Semuels, 2011; Flentje, 2012).

Proponents of the Texas model point to that state's generally stronger employment and population growth (Wall Street Journal, 2012b). Others counter by highlighting the lower per capita income growth and higher unemployment and poverty in Texas (Semuels, 2011; Flentje, 2012). The comparing of Texas's experience to that of other states directly also has been questioned because of the state's unique geographic and demographic characteristics, such as its border location and related international trade and immigration; available land and lending regulations that keep housing prices low; and historically abundant oil and gas resources that generate substantial severance tax revenues for the state (McNichol and Johnson, 2012). Texas also contains large metropolitan areas not matched in Oklahoma.

Conflicting opinions have appeared in the press on whether lower state income taxes or their absence spur economic growth. Laffer and Moore (2012) argued that states without income taxes historically have had stronger economic growth. The Institute on Taxation and Economic Policy (2012a) contends that states with the highest income tax rates have outperformed the rest during the previous decade, while those without an income tax have performed the worst. Previous reviews of the academic literature on state and local fiscal policies and growth (Bartik, 1991; Wasylenko, 1997) and my review of recent studies below indicate that the evidence varies widely and, hence, at present remains inconclusive.

Academic studies of state and local fiscal policies vary widely in their approaches and scope, with each approach possessing advantages and disadvantages. Methodological issues arise that can affect the estimated relationship between policy and outcomes, which include accounting for other economic growth influences; accurately measuring regional fiscal policy; capturing the time lag between policy and outcomes; addressing the potential endogeneity of 
policies to economic conditions; allowing for heterogeneity of responses across space; and allowing for potential nonconstancy of policy effects across time. These issues are addressed to different extents across studies that, not surprisingly then, produce highly varying findings. The study used as the basis for the Oklahoma state income tax proposal (Arduin, Laffer, and Moore Econometrics, 2011) has been correctly criticized for either not, or poorly, addressing these issues (Institute on Taxation and Economic Policy, 2012b; Maxwell, 2012; McGuigan, 2012; Olson, 2012; Shaw, 2012).

Therefore, here I examine the empirical basis for Oklahoma to eliminate its income tax. I compare the recent economic performance of Oklahoma to its neighbors and to Texas in particular because of its prominence in recent debates about state income taxes. I examine several economic indicators because the use of any single economic indicator can lead to an incomplete and incorrect portrait of regional economic well-being (Partridge and Rickman, 1999; 2003). Because of the focus on recent growth in the policy debate, growth in the various economic indicators is examined for the most recent two decades, not the extent to which policy differences have been capitalized into wages and land rents, which would reflect any previous growth advantages. Full capitalization of existing and anticipated policy differences into wages and land rents would cause current growth to be equal across areas (Partridge et al., 2008a); however, a recent review of the relevant empirical literature suggests that this does not occur broadly across U.S. regions in a timely manner (Partridge et al., forthcoming).

Because of concerns for state comparisons generally, I also specifically compare the economic performance of Oklahoma counties with those in the neighboring states, while controlling for factors that potentially produce the different outcomes observed at the state level. Yet, because there may be additional unaccounted for differences that influence the outcomes, I also examine counties that lie along the Oklahoma border. To further address the issue of Texas, I then focus solely on counties along the Oklahoma-Texas border, including examining counties in the panhandle separately to produce a quasi-matched comparison of Oklahoma-Texas counties. If state policies affect the location of activity, the effects could be greatest at the border as households and firms readily locate to nearby counties just across state borders, and still have the same relative proximity to desired markets and transportation networks.

I find that careful consideration of a wider selection of economic indicators and analysis of counties to control for exogenous differences in characteristics potentially related to economic performance, suggests that the Texas economy has not generally outperformed the Oklahoma economy. Therefore, it is misguided and potentially harmful for Oklahoma to enact policies such as eliminating the state income tax to mimic Texas. Oklahoma may be unwilling or unable to raise tax revenues from other sources as has Texas (e.g., Texas has significantly higher property taxes), which may harm needed investments in education and highways and bridges. To be sure, I also find evidence in this study indicating the importance of college graduates for economic growth, where public universities in the state may become underfunded if income taxes are eliminated.

\section{A BRIEF RECAP OF THE RECENT LITERATURE}

The academic literature on the relationship between state and local fiscal policies and economic growth has been inconclusive, often producing contradictory findings (Wasylenko, 1997). In an early survey of the literature, Bartik (1991) reported a general finding of a modest negative relationship between most state and local taxes and regional growth. Fisher (1997)

(C) Southern Regional Science Association 2013. 
further reported positive growth effects for some regional government expenditures, particularly those for highway transportation. Thus, a possible reason for the lack of a strong connection between taxes and growth is that lower taxes also imply lower expenditures, which can be positively related to economic activity. In a meta-analysis of the studies reviewed by Bartik, Goss (1995) observed that studies which fail to include variables for state and local government services find smaller negative regional tax effects. In such a study, Helms (1985) found that taxes used to finance public transfer payments such as welfare expenditures reduced growth, while those used to pay for state and local education and highways did not.

More recently, Brown et al. (2003) found that while some state and local expenditures more than offset the negative effect of taxes on economic growth, most did not. Subsequently, Taylor and Brown (2006) discovered that the net effect of the size of state and local government changed over time, having negative effects on private sector growth during the 1980s, but likely on balance maximizing private sector growth in the 1990s. Likewise, evidence uncovered by Deskins and Hill (2010) revealed that the negative effects of taxes on state private sector employment and gross state product diminished from 1985 to 2003, as the variation in the size of state and local governments diminished.

In an extensive empirical analysis, Reed (2008a) estimated the relationship between taxes and personal income growth for 1970 to 1999 for the lower 48 U.S. states. He reported that taxes used to fund general expenditures significantly reduce personal income growth. Reed showed the relationship to be robust to specifications of government finances, as well as consistent across space and time. Reed attributed the uniqueness of his results and the lack of consistency found in earlier studies to his use of five-year changes, which captured lagged responses to taxes. In a follow-up study that used Leamer's (1985) extreme bounds analysis, Reed (2008b) confirmed the negative relationship between taxes and state economic growth across a wide range of specifications, though the effect is modest. However, the studies did not address the potential endogeneity of taxes. As Reed acknowledged, if taxes are raised during periods of slow growth and lowered during periods of fast growth, ordinary least squares produces negatively-biased estimates.

Using spatial hedonic analysis of wages and housing costs and instrumental variables estimation to address potential endogeneity, Yu and Rickman (2013) found that state income taxes had negative household amenity effects during the 1990s (as well as for most other state taxes), but found positive amenity effects for state highway spending, and state spending on the environment and housing. For counties, local spending on education and safety increased firm profitability, while county spending on highways increased the household amenity attractiveness of the county. County property tax rates reduced area household amenity attractiveness, but this effect was outweighed by the positive effect for public safety, which are paid for by those tax revenues.

Holcombe and Lacombe (2004) examined counties that lie along state borders during the period running from 1960 to 1990. They argued that such an examination of border counties should minimize any influences of culture, weather, and access to markets to the point that they should be statistically insignificant. Border counties also were matched to those that were adjacent. Thus, differences in economic growth can be attributable to state policy differences to the extent adjacent county characteristics unrelated to state policies are similar. They found that counties located in states with higher personal income taxes experienced significantly slower per capita income growth over the period.

(C) Southern Regional Science Association 2013. 
In an analysis of 2000-2007, Goetz et al. (2011) did not find the top marginal personal income tax rate, the top corporate income tax rate, or the effective property tax rate as statistically associated with state employment growth. Being a right-to-work state and having a greater variety of financial assistance programs were negatively related to employment growth. Further, having a greater variety of tax incentive programs and a more lax regulatory environment were statistically insignificant. The authors surmised that the lack of influence of taxes related to their association with expenditures on productive and valued public services such as education and highways, which offset any opposing effects of differential taxation. They instead find the natural amenity attractiveness of the state as the most significant factor, while evidence also was found for employment in technology-related occupations and computer usage as positively benefitting state economies.

Alm and Rogers (2011) used annual state and local data from 1947 to 1997 for the 48 contiguous states to examine the relationship between per capita income convergence/growth and an array of state and local fiscal and political climate variables. Across a variety of specifications and alternative estimation approaches, they reported inconsistent findings for state and local taxation policies overall, in which the variables ranged from having negative, positive, or no effects at all. A state income tax variable was never found to have statistically significant negative effects, but was sometimes statistically significant and positive. Interestingly, they reported that a more "conservative political orientation" was negatively correlated with per capita income growth. Having tax and expenditure limitations (TELs) also was found to reduce state per capita income growth, a finding similarly reported by Deller et al. (2012).

Using a similar framework, Bauer et al. (2012) examine per capita income growth during the period of 1934 to 2004 . They report that state strategies to alter tax policies to spur income growth were not effective. The stock of patents held by people or businesses in the state mattered most for per capita income growth, followed by college attainment among the adult population and climate. Thus, the authors conclude that policy makers should focus on boosting the production of new technology and increasing college attainment.

\section{METHODOLOGY}

The review above suggests that the way in which state and local fiscal policies affect economic growth is far from settled. Studies continue to vary in their focus and approach, making it difficult to draw general conclusions. In an attempt to draw more definitive conclusions about Oklahoma, I focus specifically on recent economic performance for Oklahoma and neighboring states.

A single economic indicator is unlikely to represent well an economy's overall wellbeing (Partridge and Rickman, 1999; 2003). So I examine growth using a number of indicators: total employment, manufacturing employment, population, real per capita income and real private gross domestic product per employee. Because of the difficulty in controlling for all relevant growth determinants across space, potential spatial heterogeneities in regional growth dynamics (Partridge et al., 2008b) and non-constancy of fiscal policy effects across time (Taylor and Brown, 2006; Deskins and Hill, 2010), I solely compare the recent economic performance of Oklahoma with its neighbors for various recent periods. Given its prominence in current debates on lowering and repealing state income taxes, specific attention is given to Texas. To address the issue of lagged effects between policy changes and economic outcomes (Reed, 2008a), multi- 
year changes in economic outcomes are examined, including the periods 1990 to 2000 and 2000 to 2010. All data for these variables are from the U.S. Bureau of Economic Analysis.

Yet, because the neighboring states are geographically large and diverse, I then compare counties in Oklahoma with those in the neighboring states, including separately examining those along Oklahoma's border. In further analysis, I compare only Oklahoma-Texas border counties, including separating the counties in the states' panhandles from other counties along the border. ${ }^{1}$ County-level analysis provides the necessary degrees of freedom to statistically control for factors that may underlie state differences in growth. Exogenous factors that have been found to underlie regional growth differences include natural amenity attractiveness, the position along the rural-urban continuum and industry composition and industry composition (e.g., Partridge et al., 2012). Natural amenity attractiveness is measured using a ranking produced by the USDA Economic Research Service, which is based on multiple indicators of climate, topographical variation, and water coverage (McGranahan, 1999). Also included are whether the county is classified as a recreation-based county by the USDA Economic Research Service and the percent of the county covered by forests (McGranahan et al., 2011). Dummy variables are created using the 2003 USDA Economic Research Service's nine category rural-urban continuum codes. ${ }^{2}$

These exogenous factors are included in both the analysis of all counties in the neighboring states and of those along the border. Because of limited degrees of freedom, they are omitted when only the counties along the Oklahoma and Texas border are considered. Yet, the restriction of the analysis to counties along a common border between two states implicitly controls for many of these and other growth influences, especially when they are matched by region of the common border.

Industry composition also is represented by a series of binary variables based on classification by USDA Economic Research Service. Counties are designated as primarily dependent on farming, government, manufacturing, mining, and services, with diversified counties as the omitted category. Classification is based on 1998-2000 county industry shares of labor and proprietor earnings (and employment for farming).

\section{EMPIRICAL RESULTS}

\subsection{State Level Comparison}

Table 1 displays state growth rates in total employment, manufacturing employment, population, real per capita income and real private gross domestic product (GDP) per employee (a measure of labor productivity) for Oklahoma and its neighboring states for the periods 19902000 and 2000-2010. To isolate the effects of the Great Recession, the latter period also is split

\footnotetext{
${ }^{1}$ Border counties have a long history of use for examining state policy differences. Besides the Holcome and Lacombe (2004) study on state personal income taxes, other border studies have examined the effects of state right-to-work laws (Holmes, 1998), state minimum wage laws (Thompson, 2008; Dube et al., 2010), state investment tax incentives (Chirinko and Wilson, 2008), sales taxes (Burnes et al., 2011), bank branching deregulation (Huang, 2008), environmental regulations (Kahn, 2004) and economic development incentives (Patrick, 2011).

${ }^{2}$ This code denotes whether a county is: 1) in a metropolitan area with population of 1 million or more; 2) in a metropolitan area of 250,000 to 1 million people; 3 ) in a metropolitan area of fewer than 250,000 people; 4) a nonmetropolitan county with urban population of 20,000 or more, adjacent to a metropolitan area; 5) a nonmetropolitan county with urban population of 20,000 or more, not adjacent to a metropolitan area; 6) a nonmetropolitan county with urban population of 2,500-19,999, adjacent to a metropolitan area; 7) a nonmetropolitan county with urban population of 2,500-19,999, not adjacent to a metropolitan area; 8) a nonmetropolitan county completely rural or less than 2,500 urban population, adjacent to metropolitan area; or 9) a nonmetropolitan county completely rural or less than 2,500 urban population, not adjacent to metropolitan area.
}

(C) Southern Regional Science Association 2013. 
into 2000-2007 and 2007-2010. Fastest growth among the states in each period is denoted by a superscripted asterisk.

Table 1. State Growth Rate Comparison by Period, 1990-2010

\begin{tabular}{|c|c|c|c|c|}
\hline State/Period & 1990-2000 & $2000-2010$ & 2000-2007 & 2007-2010 \\
\hline \multicolumn{5}{|l|}{ Arkansas } \\
\hline Total Emp. & $24.06 \%$ & $3.61 \%$ & $5.97 \%$ & $-2.22 \%$ \\
\hline Mft Emp. & $10.32 \%$ & $-31.70 \%$ & $-19.46 \%$ & $-15.20 \%$ \\
\hline Real PCPI & $56.74 \%$ & $45.32 \%$ & $38.89 \%$ & $4.63 \%$ \\
\hline Population & $13.66 \%$ & $9.07 \%$ & $6.35 \%$ & $2.56 \%$ \\
\hline Real GDP/Emp. & $21.95 \%$ & $17.32 \%$ & $13.76 \%{ }^{*}$ & $3.37 \%$ \\
\hline \multicolumn{5}{|l|}{ Colorado } \\
\hline Total Emp. & $43.48 \%^{*}$ & $7.82 \%$ & $9.76 \%$ & $-1.76 \%$ \\
\hline Mft. Emp. & $20.94 \%{ }^{*}$ & $-28.81 \%$ & $-19.38 \%$ & $-11.69 \%$ \\
\hline Real PCPI & $75.39 \%^{*}$ & $24.45 \%$ & $25.71 \%$ & $-1.00 \%$ \\
\hline Population & $30.82 \%^{*}$ & $16.66 \%$ & $11.02 \%$ & $5.08 \%$ \\
\hline Real GDP/Emp. & $34.69 \%$ & $15.02 \%$ & $9.03 \%$ & $5.31 \%$ \\
\hline \multicolumn{5}{|l|}{ Kansas } \\
\hline Total Emp. & $19.27 \%$ & $2.69 \%$ & $4.90 \%$ & $-2.11 \%$ \\
\hline Mft. Emp. & $13.72 \%$ & $-18.18 \%{ }^{*}$ & $-5.34 \%^{*}$ & $-13.56 \%$ \\
\hline Real PCPI & $57.86 \%$ & $36.92 \%$ & $32.30 \%$ & $3.49 \%$ \\
\hline Population & $8.56 \%$ & $6.14 \%$ & $3.35 \%$ & $2.71 \%$ \\
\hline Real GDP/Emp. & $15.53 \%$ & $15.38 \%$ & $13.44 \%$ & $1.99 \%$ \\
\hline \multicolumn{5}{|l|}{ Missouri } \\
\hline Total Emp. & $16.77 \%$ & $0.56 \%$ & $4.94 \%$ & $-4.18 \%$ \\
\hline Mft. Emp. & $-5.50 \%$ & $-31.28 \%$ & $-16.25 \%$ & $-17.95 \%$ \\
\hline Real PCPI & $58.60 \%$ & $31.97 \%$ & $27.38 \%$ & $3.60 \%$ \\
\hline Population & $9.33 \%$ & $6.93 \%$ & $5.00 \%$ & $1.84 \%$ \\
\hline Real GDP/Emp. & $23.21 \%$ & $6.86 \%$ & $3.03 \%$ & $3.68 \%$ \\
\hline \multicolumn{5}{|l|}{ New Mexico } \\
\hline Total Emp. & $26.70 \%$ & $10.34 \%$ & $14.09 \%$ & $-3.28 \%$ \\
\hline Mft. Emp. & $12.33 \%$ & $-23.99 \%$ & $-9.00 \%$ & $-16.47 \%$ \\
\hline Real PCPI & $53.45 \%$ & $46.58 \%^{*}$ & $39.26 \%$ & $5.26 \%{ }^{*}$ \\
\hline Population & $19.69 \%$ & $13.44 \%$ & $9.27 \%$ & $3.81 \%$ \\
\hline Real GDP/Emp. & $67.47 \%^{*}$ & $17.55 \%^{*}$ & $6.21 \%$ & $9.48 \%{ }^{*}$ \\
\hline \multicolumn{5}{|l|}{ Oklahoma } \\
\hline Total Emp. & $21.03 \%$ & $6.61 \%$ & $7.05 \%$ & $-0.41 \%$ \\
\hline Mft. Emp. & $11.70 \%$ & $-25.06 \%$ & $-11.47 \%$ & $-15.34 \%$ \\
\hline Real PCPI & $53.03 \%$ & $43.85 \%$ & $39.54 \%{ }^{*}$ & $3.09 \%$ \\
\hline Population & $9.70 \%$ & $8.85 \%$ & $5.21 \%$ & $3.46 \%$ \\
\hline Real GDP/Emp. & $9.89 \%$ & $16.34 \%$ & $12.57 \%$ & $3.31 \%$ \\
\hline \multicolumn{5}{|l|}{ Texas } \\
\hline Total Emp. & $31.47 \%$ & $17.56 \%{ }^{*}$ & $15.41 \%{ }^{*}$ & $1.86 \%{ }^{*}$ \\
\hline Mft. Emp. & $11.24 \%$ & $-20.72 \%$ & $-10.41 \%$ & $-11.51 \%{ }^{*}$ \\
\hline Real PCPI & $65.12 \%$ & $32.64 \%$ & $33.64 \%$ & $-0.74 \%$ \\
\hline Population & $22.79 \%$ & $20.57 \%^{*}$ & $13.79 \%^{*}$ & $5.96 \%{ }^{*}$ \\
\hline Real GDP/Emp. & $25.96 \%$ & $10.06 \%$ & $8.31 \%$ & $1.32 \%$ \\
\hline
\end{tabular}

*denotes fastest growth during the period

(C) Southern Regional Science Association 2013. 
Except real private GDP per employee, Colorado experienced the fastest growth according to all economic indicators during the 1990s. Among the seven states, Oklahoma had the fifth fastest rates of total employment and population growth, fourth fastest rate of manufacturing growth, and was last in real per capita income growth and real private GDP per employee growth. Except for the case of manufacturing employment growth, the growth rates for the economic indicators of Texas exceeded those of Oklahoma.

Following the nation, the most recent decade by comparison, which contained two economic recessions, was one of slower employment growth and significant losses in manufacturing employment across all seven states. Among the states, Texas led the way in total employment and population growth. New Mexico had the fastest growth in real per capita income and real private GDP per employee. Although substantial, Kansas had the smallest decline in manufacturing employment. Despite the slower population and employment growth relative to Texas, Oklahoma experienced relatively faster growth per employee in terms of real per capita income and real private GDP.

The slightly stronger growth in population relative to employment and the relatively weaker growth in real per capita income and real per employee private GDP in Texas suggest that the growth was supply-driven through some combination of immigration and internal migration (Partridge and Rickman, 1999). Oklahoma's stronger real per capita income growth and faster growth of private real GDP relative to employment suggest demand as primarily underlying Oklahoma's growth. This is likely attributable to strength in the energy sector during the decade.

In separating out the effects of the recession, the primary difference for the 2000 to 2007 period relative to the entire decade is that Oklahoma experienced the strongest growth in real per capita income. Texas fared the best in terms of employment and population growth post-2007 but it also was one of only two states to experience a reduction in its real per capita income. Oklahoma exceeded Texas in each subperiod of the recent decade in the rate of per capita income growth and private real GDP per employee.

Arkansas, Kansas, and Texas were right-to-work states during the 1990s. Oklahoma joined them early in the following decade. Of the study states, Texas was the only one without a state income tax. Among this same set of states, personal income tax collections as a share of aggregate personal income was largest in Oklahoma in 1992 (2.20 percent), followed fairly closely by Arkansas (2.17 percent). By 2007, Kansas had the largest effective personal income tax rate, followed closely by Arkansas, and then Oklahoma. ${ }^{3}$

The negative correlations between 1990s growth and the effective personal income tax rate in 1992 ranged from -.14 for employment growth to -.35 for population growth for the seven states in the comparison. The value is approximately zero for manufacturing employment growth and positive for private productivity growth $(r=.26)$. When Texas is removed, the previously negative correlation coefficients become positive or near-zero, while productivity growth becomes more positively correlated with the 1992 state personal income tax rate. The correlations are much more negative for growth during 2000-2010 and the effective personal income tax rate in 2000, except for positive correlations for real per capita income and productivity growth.

\footnotetext{
${ }^{3}$ State tax rates for various years can be found at http://www.usgovernmentspending.com, last accessed May 25, 2013.
} 
The patterns of state growth appear to fit the common perception in the literature that the Texas economy has done well in comparison to other states. This appears to be particularly true for employment and population growth, but not as much for per capita income and per employee private GDP growth. The diversity between and within states along several dimensions makes it difficult to draw definitive conclusions regarding state policies from a simple comparison of state growth rates. Colorado ranks much higher in terms of amenity attractiveness. Given their location along the southern U.S. border, Texas and New Mexico may experience significantly greater immigration and benefits from U.S. trade with Mexico. Colorado, Oklahoma, and Texas contain significant energy resources. The states also differ in their degree of urbanization. Therefore, I next perform an analysis of the counties in the states, while attempting to control for the aforementioned differences.

\subsection{Analysis of all Counties in Oklahoma and Neighboring States}

Tables 2 and 3 display the results of regression analysis of county growth rates for Oklahoma and those of neighboring states for the periods of 1990-2000 and 2000-2010, respectively. Results are not included for real private GDP because of the absence of county level data. The maximum number of counties available for analysis in the states is 722 , where because of the absence of data for some counties, the number of counties used in each regression is less.

As shown in Table 2, all regressions for the 1990s are statistically significant. Significant variables in each regression based on two-tailed $t$-tests are emboldened. The population regression has the largest $R^{2}$, while the lowest is for manufacturing employment. As seen from the reported $F$-statistics, the state binary variables are significant as a group in each regression, even in regressions where most individual coefficients are insignificant. With Oklahoma the omitted category, this indicates that the remaining states as a group significantly differ from Oklahoma in each regression.

For 1990 to 2000, following the general findings of the literature (e.g., Deller, 2001; Rickman and Rickman, 2011) natural amenity attractiveness of the county significantly and positively influenced total employment growth. The negative and significant effect shown for the amenity ranking on manufacturing employment has been reported elsewhere (Henderson and McDaniel, 2005), which can occur if amenity attractiveness increases manufacturing costs, while not boosting demand which is national and/or international in scope. Status as a recreation county and forest cover positively and significantly influenced employment and population growth.

Counties further down in the urban/rural hierarchy (i.e., smaller and more remote) experienced increasingly slower (or more negative) total employment and population growth. Nonmetropolitan counties experienced about the same lower relative per capita income growth across categories. The only significant effect for immigration is the negative effect on per capita income growth. Energy counties experienced significantly slower growth in total employment and population over the decade. Counties specialized in services appear to have fared the best relative to non-specialized counties (the omitted category). 
Table 2. County-level Comparison across All Study States, 1990-2000 ( $p$-values in parentheses)

\begin{tabular}{|c|c|c|c|c|}
\hline & Total Emp. & Mft. Emp & PCPI & Population \\
\hline Constant & $0.32(.00)$ & $0.70(.00)$ & $0.64(.00)$ & $0.18(.00)$ \\
\hline Amenity Rank & $0.04(.06)$ & $-0.10(.02)$ & $-0.01(.48)$ & $0.01(.16)$ \\
\hline Recreation Cty & $0.17(.00)$ & $0.29(.01)$ & $0.04(.13)$ & $0.11(.00)$ \\
\hline Forest Cover*100 & $0.25(.00)$ & $-0.12(.13)$ & $0.11(.00)$ & $0.13(.00)$ \\
\hline Immigration-1990s & $-0.01(.80)$ & $-0.05(.25)$ & $-0.02(.09)$ & $0.00(.93)$ \\
\hline Texas Binary & $-0.01(.73)$ & $0.18(.05)$ & $0.03(.13)$ & $0.06(.00)$ \\
\hline Kansas Binary & $0.01(.78)$ & $0.04(.60)$ & $0.00(.95)$ & $0.01(.79)$ \\
\hline Arkansas Binary & $-0.08(.19)$ & $-0.09(.19)$ & $0.05(.10)$ & $0.00(.88)$ \\
\hline Missouri Binary & $-0.04(.46)$ & $-0.09(.19)$ & $0.10(.00)$ & $0.01(.50)$ \\
\hline Colorado Binary & $0.18(.00)$ & $0.24(.02)$ & $0.09(.01)$ & $0.17(.00)$ \\
\hline New Mex. Binary & $0.02(.77)$ & $0.12(.43)$ & $0.06(.07)$ & $0.11(.00)$ \\
\hline Farm Cty & $-0.03(.49)$ & $-0.03(.73)$ & $-0.09(.00)$ & $-0.06(.00)$ \\
\hline Energy Cty & $-0.11(.03)$ & $-0.14(.16)$ & $0.02(.36)$ & $-0.11(.00)$ \\
\hline Manufacturing Cty & $-0.02(.55)$ & $0.01(.92)$ & $-0.03(.08)$ & $-0.02(.11)$ \\
\hline Government Cty & $-0.00(.93)$ & $-0.11(.17)$ & $-0.05(.01)$ & $-0.01(.60)$ \\
\hline Services Cty & $0.17(.00)$ & $-0.01(.86)$ & $0.02(.40)$ & $0.08(.00)$ \\
\hline RuralUrban $=2$ & $-0.17(.00)$ & $-0.12(.19)$ & $-0.07(.01)$ & $-0.06(.02)$ \\
\hline RuralUrban $=3$ & $-0.29(.00)$ & $-0.20(.02)$ & $-0.09(.00)$ & $-0.16(.00)$ \\
\hline RuralUrban $=4$ & $-0.30(.00)$ & $-0.18(.09)$ & $-0.13(.00)$ & $-0.16(.00)$ \\
\hline RuralUrban $=5$ & $-0.33(.00)$ & $-0.15(.13)$ & $-0.13(.00)$ & $-0.18(.00)$ \\
\hline RuralUrban $=6$ & $-0.33(.00)$ & $-0.24(.00)$ & $-0.13(.00)$ & $-0.20(.00)$ \\
\hline RuralUrban $=7$ & $-0.36(.00)$ & $-0.06(.61)$ & $-0.13(.00)$ & $-0.22(.00)$ \\
\hline RuralUrban $=8$ & $-0.32(.00)$ & $-0.21(.08)$ & $-0.14(.00)$ & $-0.18(.00)$ \\
\hline RuralUrban $=9$ & $-0.43(.00)$ & $-0.18(.08)$ & $-0.14(.00)$ & $-0.25(.00)$ \\
\hline$F$ (States) & $3.02^{\mathrm{a}}$ & $3.16^{\mathrm{a}}$ & $4.87^{\mathrm{a}}$ & $7.57^{\mathrm{a}}$ \\
\hline$F$ (Regression) & $14.33^{\mathrm{a}}$ & $2.12^{\mathrm{a}}$ & $10.55^{\mathrm{a}}$ & $31.12^{\mathrm{a}}$ \\
\hline$R^{2}$ & .32 & .08 & .26 & .51 \\
\hline \# of observations & 719 & 600 & 719 & 719 \\
\hline
\end{tabular}

In terms of the remaining state differences, despite controlling for natural amenity attractiveness, Colorado generally grew faster than the other states. Texas had significantly faster growth in manufacturing employment and population than Oklahoma, but not in total employment or per capita income. ${ }^{4}$ Only Colorado had significantly stronger employment growth than did Oklahoma, while it was joined by Arkansas, Missouri, and New Mexico in terms of per capita income growth. Only Texas had both a right-to-work law and no personal income tax. Arkansas had a right-to-work law but an effective income tax that was similar in size to Oklahoma's. New Mexico, on the other hand, was not a right-to-work state but also had a similarly sized effective personal income tax rate. Thus, the differences clearly should not be attributable either to state personal income taxation or to right-to-work status.

\footnotetext{
${ }^{4}$ Except for total employment growth, when added, retirement-county status was positive and statistically significant in all regressions. Its addition causes the Texas coefficient to become statistically insignificant for manufacturing employment growth and to become borderline statistically insignificant for population growth (suggesting the Texas population growth differential is largely retirement migration). However, the variable is omitted from the final specifications because policy differences may in part underlie retirement destination status across states.
}

(C) Southern Regional Science Association 2013. 
Table 3. All County Comparison: 2000-2010 ( $p$-values in parentheses)

\begin{tabular}{|c|c|c|c|c|}
\hline & Total Emp. & Mft. Emp & PCPI & Population \\
\hline Constant & $0.14(.00)$ & $-0.33(.01)$ & $0.46(.00)$ & $0.16(.00)$ \\
\hline Amenity Rank & $0.01(.07)$ & $0.05(.08)$ & $-0.00(.82)$ & $0.01(.31)$ \\
\hline Recreation Cty & $.04(.04)$ & $0.07(.40)$ & $-0.00(.96)$ & $0.02(.30)$ \\
\hline Forest Cover*100 & $-0.01(.64)$ & $-0.27(.00)$ & $-0.08(.01)$ & $0.05(.00)$ \\
\hline Immigration-1990s & $0.40(.15)$ & $-0.83(.44)$ & $-1.99(.00)$ & $1.20(.00)$ \\
\hline Texas Binary & $.05(.00)$ & $.08(.20)$ & $.04(.11)$ & $.01(.39)$ \\
\hline Kansas Binary & $-0.06(.01)$ & $0.11(.11)$ & $-0.02(.42)$ & $-0.05(.00)$ \\
\hline Arkansas Binary & $-0.06(.01)$ & $-0.10(.16)$ & $-0.01(.68)$ & $-0.04(.04)$ \\
\hline Missouri Binary & $-0.07(.00)$ & $-0.06(.33)$ & $-0.12(.00)$ & $-0.01(.67)$ \\
\hline Colorado Binary & $-0.03(.27)$ & $0.04(.68)$ & $-0.07(.04)$ & $-0.02(.30)$ \\
\hline New Mex. Binary & $0.02(.48)$ & $0.01(.94)$ & $0.07(.07)$ & $-0.03(.24)$ \\
\hline Farm Cty & $-0.03(.09)$ & $0.11(.17)$ & $-0.02(.41)$ & $-0.05(.00)$ \\
\hline Energy Cty & $0.07(.08)$ & $0.25(.03)$ & $0.08(.00)$ & $-0.01(.67)$ \\
\hline Manufacturing Cty & $-0.05(.00)$ & $-0.06(.06)$ & $-0.03(.09)$ & $-0.02(.11)$ \\
\hline Government Cty & $0.01(.46)$ & $-0.01(.87)$ & $0.04(.10)$ & $-0.01(.37)$ \\
\hline Services Cty & $0.03(.21)$ & $-0.11(.06)$ & $-0.04(.12)$ & $0.04(.00)$ \\
\hline RuralUrban $=2$ & $-0.05(.02)$ & $-0.03(.60)$ & $0.08(.01)$ & $-0.06(.00)$ \\
\hline RuralUrban $=3$ & $-0.13(.00)$ & $0.06(.41)$ & $0.07(.01)$ & $-0.12(.00)$ \\
\hline RuralUrban $=4$ & $-0.14(.00)$ & $-0.07(.29)$ & $0.09(.01)$ & $-0.15(.00)$ \\
\hline RuralUrban $=5$ & $-0.10(.00)$ & $0.04(.69)$ & $0.14(.00)$ & $-0.12(.00)$ \\
\hline RuralUrban $=6$ & $-0.16(.00)$ & $0.01(.84)$ & $0.13(.00)$ & $-0.17(.00)$ \\
\hline RuralUrban=7 & $-0.18(.00)$ & $-0.03(.63)$ & $0.13(.00)$ & $-0.17(.00)$ \\
\hline RuralUrban $=8$ & $-0.15(.00)$ & $-0.07(.51)$ & $0.15(.00)$ & $-0.18(.00)$ \\
\hline RuralUrban $=9$ & $-0.12(.00)$ & $-0.02(.81)$ & $0.18(.00)$ & $-0.19(.00)$ \\
\hline$F$ (States) & $12.10^{\mathrm{a}}$ & $4.13^{\mathrm{a}}$ & $10.94^{\mathrm{a}}$ & $5.66^{\mathrm{a}}$ \\
\hline$F$ (Regression) & $16.09^{\mathrm{a}}$ & $4.57^{\mathrm{a}}$ & $10.81^{\mathrm{a}}$ & $25.02^{\mathrm{a}}$ \\
\hline$R^{2}$ & .35 & .16 & .26 & .45 \\
\hline \# of observations & 718 & 564 & 718 & 718 \\
\hline
\end{tabular}

Turning to the 2000 to 2010 period, from Table 3 it can be seen that again all regressions are statistically significant. The pattern for $R^{2}$ is the same as for the previous decade. Again, the state binary variables are statistically significant as a group in each regression.

Natural amenity attractiveness continued to be related to total employment growth, as was status as a recreation county, and also now positively influenced manufacturing employment growth. Forest cover positively influenced population growth but negatively affected per capita income growth and manufacturing employment growth. Immigration became significantly and positively related to growth in population, while also negatively influencing per capita income growth. Counties that specialized in the energy sector had faster total and manufacturing employment growth, in addition to faster per capita income growth. Following the national trend, manufacturing counties performed poorly over the decade. Growth was stronger in the largest urban areas for total employment and population growth, though there were no longer increasingly negative growth penalties for counties further down the urban/rural hierarchy.

In terms of state differences, Colorado no longer led the way in growth. Texas experienced much stronger employment growth than did Oklahoma once other influences were 
controlled for, such as immigration and energy dependence of the county. Yet, in analysis not shown, running the regressions separately for 2000-2007 and 2007-2010, revealed that the significantly stronger growth in Texas only occurred during the 2007-2010 period, in which during 2000-2007 Oklahoma and Texas were not statistically distinguishable. If the growth differences derived from policy differences, it would be expected to also have been evident during the 2000-2007 period. For example, national defense spending on goods and services surged during the 2007-2010 period, and Texas has been reported to be the third most economically sensitive state to U.S. military buildups (Nakamura and Steinsson, 2011). Texas also has been estimated to have had a much greater percentage increase in employment from the American Recovery and Reinvestment Act of 2009 than Oklahoma (Zandi, 2009). The other state faring well was New Mexico. It possessed the strongest growth in per capita income but, like Texas, this only occurred during the 2007-2010 period. Arkansas and Kansas fared poorly in terms of total employment and population growth, a result that also held true during from 2000 through 2007.

In further results not shown, adding educational attainment among adults 25 years and older reveals significant positive economic effects for college education. The share of the adult population with a bachelor's degree or more in 2000 significantly increased employment, per capita income and population growth over the 2000-2010 period. Universities and college graduates spur growth both by increasing productivity and by increasing the quality of life in an area (Winters, 2011a, 2011b). The shares with only a high school degree or an associate degree were insignificant. Beginning of period values were used to avoid direct endogeneity. Yet, the variables were not included in the final specification because of their potential relation to state spending on education, whereby, the state variables are used to capture the net effects of all policy differences.

\subsection{Analysis of Border Counties}

Because there may be important unaccounted for differences between the states, I next examine the counties that are positioned along the Oklahoma border. For example, numerous counties in Texas are on the Gulf Coast, while both New Mexico and Texas share an international border. While the international border influence on immigration should mostly be accounted for by the immigration variable included in the regression, there may be unaccountedfor international trade effects. Use of border counties greatly reduces the number of counties examined, but it more effectively identifies state differences in growth as attributable to policy differences. Colorado and New Mexico each have only one county bordering Oklahoma.

Table 4 displays results from estimation of two alternative models for each variable and period. The base model only includes the binary variables for the states, omitting that for Oklahoma. Thus, each binary variable is interpreted as the growth differential from Oklahoma for the variable and period. The full model then includes the variables used in the analysis of all counties above. For brevity, the results for these control variables are not shown, but generally follow the patterns for all counties displayed in Tables 2 and 3.

As shown in the bottom rows of Table 4, the population regressions have the largest $R^{2} \mathrm{~s}$ and were the only consistently statistically significant regressions. Other significant regressions include the full model for total employment growth during the 1990s and both models of real per capita growth post-2000. There are few statistically significant state differences. 
Table 4: Border-County Comparisons ( $p$-values in parentheses)

\begin{tabular}{|c|c|c|c|c|}
\hline State/Period & 1990-2000-base & 1990-2000-full & 2000-2010-base & 2000-2010-full \\
\hline \multicolumn{5}{|l|}{ Texas } \\
\hline Total Emp. & $-0.00(.94)$ & $0.02(.70)$ & $0.00(.92)$ & $0.06(.22)$ \\
\hline Mft Emp. & $0.17(.40)$ & $0.23(.45)$ & $0.18(.23)$ & $0.35(.09)$ \\
\hline PCPI & $-0.00(.96)$ & $0.01(.75)$ & $-0.07(.13)$ & $-0.06(.24)$ \\
\hline Population & $0.02(.48)$ & $0.02(.58)$ & $0.01(.68)$ & $0.03(.22)$ \\
\hline \multicolumn{5}{|l|}{ Kansas } \\
\hline Total Emp. & $-0.07(.24)$ & $0.02(.78)$ & $-0.06(.21)$ & $-0.03(.64)$ \\
\hline Mft. Emp. & $-0.12(.63)$ & $-0.10(.67)$ & $0.20(.24)$ & $0.24(.27)$ \\
\hline PCPI & $0.01(.85)$ & $0.02(.45)$ & $-0.00(.93)$ & $-0.02(.71)$ \\
\hline Population & $-0.03(.43)$ & $0.01(.77)$ & $-0.05(.08)$ & $-0.02(.42)$ \\
\hline \multicolumn{5}{|l|}{ Arkansas } \\
\hline Total Emp. & $0.16(.03)$ & $0.08(.42)$ & $-0.03(.66)$ & $-0.02(.77)$ \\
\hline Mft. Emp. & $-0.03(.92)$ & $0.36(.35)$ & $-0.05(.81)$ & $0.01(.97)$ \\
\hline PCPI & $0.06(.33)$ & $-0.01(.79)$ & $-0.15(.02)$ & $-0.04(.65)$ \\
\hline Population & $0.19(.00)$ & $0.08(.18)$ & $0.13(.00)$ & $0.06(.20)$ \\
\hline \multicolumn{5}{|l|}{ Missouri } \\
\hline Total Emp. & $0.13(.31)$ & $0.21(.15)$ & $0.01(.92)$ & $0.12(.36)$ \\
\hline Mft. Emp. & $-0.13(.78)$ & $0.14(.76)$ & $0.09(.77)$ & $0.59(.17)$ \\
\hline PCPI & $0.18(.11)$ & $0.07(.33)$ & $-0.11(.37)$ & $-0.09(.50)$ \\
\hline Population & $0.20(.03)$ & $0.21(.02)$ & $0.08(.24)$ & $0.06(.39)$ \\
\hline \multicolumn{5}{|l|}{ Colorado } \\
\hline Total Emp. & $0.01(.95)$ & $0.10(.53)$ & $-0.10(.51)$ & $-0.13(.39)$ \\
\hline Mft. Emp. & NA & NA & $\mathrm{NA}$ & $\mathrm{NA}$ \\
\hline PCPI & $-0.10(.52)$ & $-0.01(.91)$ & $0.16(.34)$ & $0.18(.26)$ \\
\hline Population & $-0.04(.78)$ & $0.05(.62)$ & $-0.16(.08)$ & $-0.13(.12)$ \\
\hline \multicolumn{5}{|l|}{ New Mexico } \\
\hline Total Emp. & $-0.02(.89)$ & $0.07(.68)$ & $-0.09(.57)$ & $-0.11(.45)$ \\
\hline Mft. Emp. & NA & NA & NA & NA \\
\hline PCPI & $0.14(.38)$ & $0.10(.23)$ & $-0.57(.00)$ & $-0.53(.00)$ \\
\hline Population & $-0.01(.93)$ & $0.07(.49)$ & $0.08(.40)$ & $0.10(.20)$ \\
\hline \multicolumn{5}{|l|}{ Regression $R^{2}$} \\
\hline Total Emp. & $.12(\mathrm{~N}=76)$ & $.50^{\mathrm{a}}(\mathrm{N}=76)$ & $.04(\mathrm{~N}=76)$ & $.34(\mathrm{~N}=76)$ \\
\hline Mft. Emp. & $.03(\mathrm{~N}=57)$ & $.24(\mathrm{~N}=57)$ & $.06(\mathrm{~N}=53)$ & $.35(\mathrm{~N}=53)$ \\
\hline PCPI & $.06(\mathrm{~N}=76)$ & $.23(\mathrm{~N}=76)$ & $.21^{\mathrm{a}}(\mathrm{N}=76)$ & $.49^{\mathrm{a}}(\mathrm{N}=76)$ \\
\hline Population & $.25^{\mathrm{a}}(\mathrm{N}=76)$ & $.68^{\mathrm{a}}(\mathrm{N}=76)$ & $.27^{\mathrm{a}}(\mathrm{N}=76)$ & $.59^{\mathrm{a}}(\mathrm{N}=76)$ \\
\hline
\end{tabular}

${ }^{a}$ denotes significant at or below the 0.10 level

Although most coefficients for Texas, other than for per capita income, are positive, only the coefficient for manufacturing employment growth in the full model is statistically significant. The positive coefficients are statistically insignificant, even where quantitatively, because the differences in growth were not consistently positive for most Texas border counties, exhibiting large variation. Missouri experienced significantly greater population growth during the 1990s according to both models. Arkansas's significant coefficients in the base model become insignificant in the full model when I control for differences in amenity attractiveness, position in the rural-urban continuum and industry structure. The significant differences for Colorado and New Mexico pertain to a single county in each of the states.

(C) Southern Regional Science Association 2013. 
Finally, to more specifically address the comparison of Oklahoma to Texas, additional regressions are run for each variable and period using only the counties along the OklahomaTexas border. Because there are only 36 such counties (16 for Oklahoma and 20 for Texas), I only estimate the base model. In addition, separate base model regressions are run for the border counties in the panhandles of the two states. These regressions best capture the matching approach of Holcombe and Lacombe (2004), in which it is argued that the closest (or adjacent) counties provide the best comparison for policy identification purposes. There are 16 Oklahoma and Texas counties along the border in the panhandle, with 20 others along the remaining (Red River) part of the Oklahoma-Texas border.

Table 5 shows that the only statistically significant difference is the lower growth of per capita income during 2000-2010, specifically in the Texas panhandle counties. These counties appear to have had stronger employment and population growth. These differences were not statistically significant, however. This fits a pattern noted above for the state of Texas, one of supply-induced growth, which was confirmed when international immigration was included in the full models. According to Census intercensal estimates, all Texas panhandle counties experienced positive immigration but negative net internal migration. Most of the other differences are not only statistically insignificant but also quantitatively small.

Table 5. Oklahoma-Texas Border-County Comparison ( $p$-values in parentheses)

\begin{tabular}{|c|c|c|}
\hline & $\mathbf{1 9 9 0 - 2 0 0 0}$ & $\mathbf{2 0 0 0 - 2 0 1 0}$ \\
\hline Total Employment & & $0.01(.86)$ \\
\hline Texas Effect & $-0.01(.84)$ & $0.08(.30)$ \\
\hline Panhandle & $-0.09(.48)$ & $-0.05(.53)$ \\
\hline Red River & $0.05(.51)$ & \\
\hline Mft Employment & & $0.21(.41)$ \\
\hline Texas Effect & $0.14(.69)$ & $0.35(.72)$ \\
\hline Panhandle & $0.36(.79)$ & $-0.02(.91)$ \\
\hline Red River & $-0.06(.86)$ & $\mathbf{- 0 . 1 3 ( . 0 4 )}$ \\
\hline Per Capita Personal Income & & $\mathbf{- 0 . 2 0}(\mathbf{0 4})$ \\
\hline Texas Effect & $-0.01(.89)$ & $-0.07(.35)$ \\
\hline Panhandle & $-0.06(.61)$ & \\
\hline Red River & $0.04(.39)$ & $0.02(.56)$ \\
\hline Population & & $0.05(.28)$ \\
\hline Texas Effect & $0.04(.27)$ & $-0.01(.81)$ \\
\hline Panhandle & $0.04(.54)$ & \\
\hline Red River & $0.05(.31)$ & \\
\hline
\end{tabular}

(C) Southern Regional Science Association 2013. 


\section{DISCUSSION AND CONCLUSIONS}

This paper addresses the issue of whether Texas should serve as an economic policy model for Oklahoma and other nearby states. Advocates point to the generally stronger employment and population growth of Texas (Wall Street Journal, 2012b). Critics point to the lower per capita income growth and higher unemployment and poverty in Texas (Semuels, 2011; Flentje, 2012). Questions also have been raised regarding whether Texas's experience relates to its economic policies or other unique features of the state (McNichol and Johnson, 2012).

Therefore, this paper compared the recent economic performance of Oklahoma to that of its neighboring states, with particular focus on Texas. Two broad methodological issues were addressed. The first issue was correctly interpreting the various indicators of state economic performance. The second was properly comparing the states' economic experiences to infer lessons for economic policy.

A comparison of the state averages revealed generally stronger employment and population growth for Texas relative to Oklahoma, though Colorado had the strongest growth in the 1990s among all adjacent states. Texas also had relatively weaker growth in per capita income and real private GDP per employee growth relative to population growth, suggesting that growth in Texas was primarily supply driven, through some combination of immigration and internal migration (Partridge and Rickman, 1999). Yet, because of other differences between the states not related to policy, definitive lessons for policy could not be drawn from the comparison.

I next compared county-level growth for Oklahoma and neighboring states. An advantage of using county level data is that variables could be added to control for differences in natural amenity attractiveness, the county's position in the rural-urban continuum, the industry dependency or specialization of the county and the rate of international immigration into the county. Residual (unexplained) differences in economic performance were captured by binary state variables.

During the 1990s, the binary variables revealed that Texas had significantly faster residual growth in manufacturing employment and population than Oklahoma, but not in total employment or real per capita income for which there were no statistical differences. Post-2000, Texas experienced significantly stronger employment growth than Oklahoma once other influences were controlled for such as immigration and energy dependence of the county. But these differences only were only significant during the 2007-2010 period, a period where Texas particularly benefitted from increased federal spending.

Because other unaccounted-for differences remained such as Texas's proximity to the Gulf coast, its border with Mexico and possible differences in culture, I next compared the counties that are positioned along the Oklahoma border. First, border counties of all neighboring states were included, in which a model only containing the state binary variables and then a model adding all previous control variables were estimated. The only statistically significant advantage for Texas was found for manufacturing employment growth during the 2000 to 2010 period.

To more directly compare Oklahoma and Texas, I next solely examined the counties along the Oklahoma-Texas border. Given that the counties should share most nonpolicy characteristics and because of the limited number of observations, the estimated regressions only included the state binary variables. I also compared the counties in the panhandles of the two 
states separately from the other border counties. This produced a quasi-matching comparison. The only statistically significant effect for Texas was the lower per capita income growth in Texas during 2000-2010, a result that appeared mostly to occur in the panhandle counties. Although not statistically significant, the Texas panhandle counties also experienced stronger manufacturing employment and population growth. Along with positive immigration, this suggests that growth in the counties occurred in low-paying manufacturing plants, possibly disproportionately employing immigrants.

In conclusion, there is not compelling evidence that Texas economically outperforms Oklahoma. Differences in growth at the state level appear mostly driven by labor supply, in which immigration is a significant contributing factor. Controlling for other differences between Oklahoma and Texas using county level data for all neighboring states revealed few growth advantages, in which the only advantage post-2000 occurred during 2007 to 2010 . Notably, Texas did not enjoy any advantages during the 2000 to 2007 period, which is prior to when Oklahoma continued to reduce its personal income tax rate. Most telling is that in an analysis of all border counties, the only positive evidence found for Texas was stronger manufacturing employment growth. In focusing solely on counties along the Oklahoma-Texas border, I found significantly slower per capita income growth in Texas, specifically in the panhandle counties. Given their initial lower levels of per capita income, slower real per capita income growth in these counties is not consistent with a convergence argument.

Texas was used as an example of why Oklahoma needed to enact a right-to-work law. The county-level evidence above suggests that Oklahoma did not experience improved economic outcomes relative to Texas after enacting right-to-work (RTW) legislation in 2001. In fact, in a recent study, using a synthetic control approach in an effort to create an experimental setting, Eren and Ozbeklik (2011) conclude that the RTW law in Oklahoma did not affect its manufacturing employment, per capita income or private sector average wages, though it did reduce union membership.

The evidence above suggests that eliminating the state income tax at best would have no impact. At worst, if Oklahoma's adjustment to elimination of the state income tax in terms of spending and alternative taxes is worse than that of Texas, the Oklahoma economy could be harmed. Vital investments in education and infrastructure could be harmed, which could more than offset any gains from reducing income taxes. Also, it is not clear that sales or property taxes are any more desirable than income taxes (Yu and Rickman, 2013). This does not mean that improvements could not be made such as eliminating ineffective and distortionary incentives and replacing them with lower tax rates, but this has proven to be difficult politically. Given the potential for adverse effects on the overall economy and on many of its citizens, the evidence presented in this paper suggests that Oklahoma should proceed cautiously when considering any changes in state taxation and spending as likely more harm than good will result.

\section{EPILOGUE}

A reduction in the Oklahoma state income tax cut to 5 percent scheduled to take effect January 1, 2015, ultimately was signed into law during the 2013 legislative session, in which the rate would be reduced further to 4.85 percent in 2016 if there was sufficient revenue growth. ${ }^{5}$ In the 2013 session, the Kansas legislature approved reducing the top personal income tax rate from

\footnotetext{
${ }^{5}$ See http://capitolbeatok.com/reports/gov-fallin-signs-income-tax-cut-to-take-effect-in-2015, accessed May 25, 2013.
}

(C) Southern Regional Science Association 2013. 
4.9 to 3.9 percent and the bottom rate to 2.3 percent. To offset the anticipated loss of personal income tax revenue, the state sales tax was set at 6.15 percent instead of the rate of 5.7 percent that was scheduled to go into effect (Cooper, 2013). The measure was later signed into law by Governor Brownback (Kraske and Murdock, 2013).

\section{REFERENCES}

Alm, James and Janet Rogers. (2011) "Do State Fiscal Policies Affect State Economic Growth?," Public Finance Review, 39, 483-526.

Arduin, Laffer and Moore Econometrics. (2011) Eliminating the State Income Tax in Oklahoma: An Economic Assessment, Oklahoma Council of Public Affairs, November.

Bartik, Timothy J. (1991) Who Benefits from State and Local Economic Development Policies? W. E. Upjohn Institute: Kalamazoo, MI.

Bauer, Paul B., Mark E. Schweitzer, and Scott A. Shane. (2012) "Knowledge Matters: The Long-Run Determinants of State Income Growth," Journal of Regional Science, 52, 240255.

Brown, Stephen P.A., Kathy J. Hayes, and Lori L. Taylor. (2003) "State and Local Policy, Factor Markets and Regional Growth," Review of Regional Studies, 33, 40-60.

Burnes, Daria, David Neumark, and Michelle White. (2011) Fiscal Zoning and Sales Taxes: Do Higher Sales Taxes Lead to more Retailing and Less Manufacturing? NBER Working Paper 16932. National Bureau of Economic Research: Cambridge, MA. Accessed at http://www.nber.org/papers/w16932.

Chirinko, Robert S. and Daniel J. Wilson. (2008) "State Investment Tax Incentives: A Zero-Sum Game?," Journal of Public Economics, 92, 2362-2384.

Cooper, Brad. (2013) "Kansas Legislature Finally Passes Tax Plan,” Kansas City Star, June 2. Accessed July 4, 2013 at http:/www.kansascity.com/2013/06/02/4268064/kansaslegislature-pushes-toward.html.

Deller, Steven, Tsung-Hsiu Tsai, David Marcouiller, and Donald English. (2001) "The Role of Amenities and Quality of Life in Rural Economic Growth," American Journal of Agricultural Economics, 83, 352-365.

Deller, Steven, Judith I. Stallmann, and Lindsay Amiel. (2012) "The Impact of State and Local Tax and Expenditure Limitations on State Economic Growth," Growth and Change, 43, 56-84.

Deskins, John and Brian Hill. (2010) "State Taxes and Economic Growth Revisited: Have Distortions Changed?," Annals of Regional Science, 44, 331-348.

Dube, Arindrajit, T. William Lester, and Michael Reich. (2010) "Minimum Wage Effects across State Borders: Estimates Using Contiguous Counties," Review of Economics and Statistics, 92, 945-964.

Eren, Ozkan and I. Serkan Ozbeklik. (2011) "Right-to-Work Laws and State-Level Economic Outcomes: Evidence from the Case Studies of Idaho and Oklahoma Using Synthetic Control Method," unpublished manuscript last accessed on September 4, 2012, at econweb.umd.edu/ davis/eventpapers/OzbeklikRight.pdf.

(C) Southern Regional Science Association 2013. 
Fisher, Ronald C. (1997) "The Effects of State and Local Public Services on Economic Development," New England Economic Review, March-April, 53-67.

Flentje, H. Edward. (2012) "Being Like Texas is Not a Panacea," Wichita Eagle, March 11.

Goetz, Stephan, Mark D. Partridge, Dan S. Rickman, and Shibalee Majumdar. (2011) "Sharing the Gains of Local Economic Growth: Race to the Top vs. Race to the Bottom Economic Development Policies," Environment and Planning C, 29, 428-456.

Goss, Ernie P. (1995) "The Effect of State and Local Taxes on Economic Development," Southern Economic Journal, 62, 320-333.

Hanna, John. (2013) "Kansas Senate Advances Income, Sales Tax Bill," Houston Chronicle, March 13. Accessed on March 17, 2013 at http://www.chron.com/news/article/KansasSenate advances-income-sales-tax-bill-4351156.php.

Helms, L. Jay. (1985) "The Effect of State and Local Taxes on Economic Growth: A TimeSeries Cross Section Approach," Review of Economics and Statistics, 67, 574-582.

Henderson, Jason R. and Kendall McDaniel. (2005) "Natural Amenities and Rural Employment Growth," Review of Regional Studies, 35, 80-96.

Holcombe, Randall G. and Donald J. Lacombe. (2004) “The Effect of State Income Taxation on Per Capita Income Growth,” Public Finance Review, 32, 292-312.

Holmes, Thomas J. (1998) "The Effect of State Policies on the Location of Manufacturing: Evidence from State Borders," Journal of Political Economy, 106, 667-705.

Huang, Rocco R. (2008) "Evaluating the Real Effect of Bank Branching Deregulation: Comparing Contiguous Counties across US State Borders," Journal of Financial Economics $_{2}$ 87, 678-705.

Institute on Taxation and Economic Policy. (2012a) "High Rate" Income Tax States Are Outperforming No-Tax States: Don't be Fooled by Junk Economics. Last accessed on September 4, 2012, at www.itepnet.org/pdf/junkeconomics.pdf.

Institute on Taxation and Economic Policy. (2012b) Arthur Laffer Regression Analysis is Fundamentally Flawed, Offers No Support for Economic Growth Claims. Last accessed on September 4, 2012 at www.itepnet.org/pdf/LafferRegression.pdf.

Jones, Tim. (2013) "Bleeding Kansas Shows Peril of GOP Bid to End Income Tax," Bloomberg, January 24. Accessed on March 17, 2013, at http://www.bloomberg.com/news/2013-0125/kansas-bonds-left-behind-highlight-risks-of-levy-cuts-taxes.html.

Kahn, Matthew E. (2004) "Domestic Pollution Havens: Evidence from Cancer Deaths in Border Counties," Journal of Urban Economics, 56, 51-69.

King, Neil and Mark Peters. (2013) "Party Eyes 'Red-State Model' to Drive Republican Revival," Wall Street Journal, February 4. Accessed on March 17, 2013, at http://online.wsj.com/article/SB10001424127887324761004578281932072421560.html.

Kraske, Steve and Zach Murdock. (2013) "Brownback Signs Kansas Measure," Kansas City Star, June 13. Accessed July 4, 2013, at http://www.kansascity.com/2013/06/13/4290891/brownback-signs-tax-bill.html.

(C) Southern Regional Science Association 2013. 
Laffer, Arthur and Stephen Moore. (2012) "A 50-State Tax Lesson for the President," Wall Street Journal Online, April 20.

Leamer, Edward E. (1985) "Sensitivity Analyses Would Help," American Economic Review, 75, 308-313.

Malm, Elizabeth and Joseph Henchman. (2013) "Kansas May Face Budget Problems as Senate Again Strips Tax Reform Out of Tax Cut Bill," Tax Foundation, March 15. Accessed on March 17, 2013, at http://taxfoundation.org/blog/kansas-may-face-budget-problemssenate-again-strips-tax-reform-out-tax-cut-bill.

Maxwell, Sally. (2012) "Income Tax Phase Out gets Cool Reception," Sequoyah County Times, last accessed on July 1, 2012, at http://sequoyahcountytimes.com/printer_friendly/18277162.

McGranahan, David A. (1999) Natural Amenities Drive Rural Population Change, AER 781. Economic Research Service, U.S. Department of Agriculture: Washington D.C.

McGranahan, David A., Timothy R. Wojan, and Dayton M. Lambert. (2011) "The Rural Growth Trifecta: Outdoor Amenities, Creative Class and Entrepreneurial Context," Journal of Economic Geography, 11, 529-557.

McGuigan, Patrick. (2012) "Oklahoma Policy Institute Speakers Slam Laffer Study, Oppose Income Tax Phase Out," CAPITOLBEATOK, April 5. Last accessed May 26, 2013, at http://capitolbeatok.com/reports/oklahoma-policy-institute-speakers-slam-laffer-studyoppose-income-tax-phase-out.

McGuigan, Patrick. (2013) "Surrounded by Low-tax States, Oklahoma is an 'Income-tax Sandwich," Watchdog.org, February 5. Accessed on March 17, 2013, at http://watchdog.org/68246/surrounded-by-low-tax-states-oklahoma-is-an-income-taxsandwich/.

McNichol, Elizabeth and Nicholas Johnson. (2012) "The Texas Economic Model: Hard for other States to Follow and Not All it Seems," Center on Budget and Policy Priorities. Last accessed on September 4, 2012, at www.cbpp.org/cms/index.cfm?fa=view\&id=3739.

Morris, Frank. (2013) 'In Kansas, A 'Glide Path' to No Income Taxes. Will it Work?,” NPR, February 15. Last accessed May 26, 2013, at http://www.npr.org/2013/02/15/171822472/in-kansas-a-glide-path-to-no-income-taxes-will-it-work.

Murphy, Sean. (2013) “Oklahoma Senate Approves Plan to Reduce Income Tax," San Francisco Chronicle, March 11. Accessed March 17, 2013, at http://www.sfgate.com/news/article/Oklahoma-Senate-approves-plan-to-reduce-income-tax-4345894.php.

Nakamura, Emi and Jón Steinsson. (2011) Fiscal Stimulus in a Monetary Union: Evidence from U.S. Regions, NBER Working Papers 17391. National Bureau of Economic Research: Cambridge, MA.

Oliff, Phil, Chris Mai, and Michael Leachman. (2012) New School Year Brings More Cuts in State Funding for Schools, Center on Budget and Policy Priorities, September 4. Accessed on March 17, 2013, at http://www.cbpp.org/cms/index.cfm?fa=view\&id=3825.

Olson, Kent. (2012) "Laffer's Invalid Case for Phasing Out Oklahoma's Income Tax," State Tax Notes, 65, September 24, p. 851.

(C) Southern Regional Science Association 2013. 
Partridge, Mark D. and Dan S. Rickman. (1999) "Which Comes First, Jobs or People? An Analysis of the Recent Stylized Facts," Economics Letters, 64, 117-123.

. (2003) "Do We Know Economic Development When We See It?," Review of Regional Studies, 33, 17-39.

Partridge, Mark D., Dan S. Rickman, Kamar Ali, and M. Rose Olfert. (2008a) "Employment Growth in the American Urban Hierarchy: Long Live Distance," B.E. Journal of Macroeconomics: Contributions to Macroeconomics, 8(1), 1-36.

(2008b) "The Geographic Diversity of U.S. Nonmetropolitan Growth Dynamics: A Geographically Weighted Regression Approach," Land Economics, 84, 241-266.

Partridge, Mark D., Dan S. Rickman, M. Rose Olfert, and Kamar Ali. (2012) "Dwindling U.S. Internal Migration: Evidence of Spatial Equilibrium or Structural Shifts in Local Labor Markets?," Regional Science and Urban Economics, 42, 375-388.

Partridge, Mark D., Dan S. Rickman, M. Rose Olfert, and Ying Tan. (Forthcoming) "When Spatial Equilibrium Fails: Is Place-based Policy Second Best?," Regional Studies.

Patrick, Carlianne. (2011) "Do More Economic Development Incentives Result in More Jobs? An Examination of the Influence of the Economic Development Incentives Environment on County Jobs in the US 1970-2000," unpublished manuscript last accessed on July 1, 2012, at aede.osu.edu/sites/drupal-aede.web/.../Patrick_State_Incentives.pdf.

Reed, W. Robert. (2008a) "The Robust Relationship between Taxes and U.S. State Income Growth," National Tax Journal, 61, 57-80.

. (2008b) "The Determinants of U.S. State Economic Growth: A Less Extreme Bounds Analysis," Economic Inquiry, 47, 685-700.

Rickman, Dan S. and Shane D. Rickman. (2011) "Population Growth in High Amenity Nonmetropolitan Areas: What's the Prognosis?," Journal of Regional Science, 51, 863879.

Semuels, Alana. (2011) "Texas isn't Stealing California jobs, Workers or Wealth, UCLA study Finds," Los Angeles Times, March 10.

Shaw, Lynne. (2012) “Anti-tax Group's Flawed 'Research'," Tulsa World, April 11.

Shields, Mike. (2012) “State Faces \$328 Million Budget Hole," KHI News Service, November 6. Accessed at http://www.khi.org/news/2012/nov/06/state-faces-328-million-budgethole/ on December 26, 2012.

Tax Foundation. (2013) Facts and Figures: How Does Your State Compare? Washington, D.C.

Taylor, Lori L. and Stephen P.A. Brown. (2006) "The Private Sector Impact of State and Local Government," Contemporary Economic Policy, 24, 548-562.

Thompson, Michael F. (2008) "Minimum Wage Impacts on Employment: A Look at Indiana, Illinois, and Surrounding Midwestern States," Indiana Business Review, 1-6.

Wall Street Journal. (2012a) "Oklahoma Reform Showdown; A Plan to Phase Out the Income Tax, if Republicans Allow It," Wall Street Journal Online, May 15.

(C) Southern Regional Science Association 2013. 
. (2012b) "The Heartland Tax Rebellion; More States Want to Repeal their Income Taxes," Wall Street Journal Online, February 7.

Wasylenko, Michael. (1997) "Taxation and Economic Development: The State of the Economic Literature," New England Economic Review, March, 37-52.

Wertz, Joe. (2012) “Three Reasons Oklahoma's Income Tax Cut Plan Failed," State Impact, May 25. Accessed on March 17, 2013, at http://stateimpact.npr.org/oklahoma/2012/05/25/three-reasons-oklahomas-income-tax-cut-plan-failed/.

Winters, John V. (2011a) "Human Capital and Population Growth in Nonmetropolitan Counties: The Importance of College Student Migration," Economic Development Quarterly, 25, $353-365$.

. (2011b) "Human Capital, Higher Education Institutions, and Quality of Life," Regional Science and Urban Economics, 41, 446-454.

Yu, Yihua and Dan S. Rickman. (2013) "U.S. State and Local Fiscal Policies and Nonmetropolitan Area Economic Performance: A Spatial Equilibrium Analysis," Papers in Regional Science, 92(3), 579-597.

Zandi, Mark. (2009) "The Economic Impact of the American Recovery and Reinvestment Act," January 21. Moody's Analytics: West Chester, PA. Last accessed November 2013 at http://www.economy.com/mark-zandi/documents/economic_stimulus_house_plan_012109.pdf.

(C) Southern Regional Science Association 2013. 
Appendix 1. Counties along the Oklahoma Border and FIPS Codes

\begin{tabular}{|c|c|c|c|c|c|}
\hline \multirow[t]{30}{*}{ Oklahoma } & Adair & 40001 & \multirow[t]{20}{*}{ Texas } & Bowie & 48037 \\
\hline & Alfalfa & 40003 & & Childress & 48075 \\
\hline & Beaver* & 40007 & & Clay & 48077 \\
\hline & Beckham* & 40009 & & $\begin{array}{c}\text { Collingswort } \\
\mathrm{h}\end{array}$ & 48087 \\
\hline & Bryan* & 40013 & & Cooke & 48097 \\
\hline & Choctaw* & 40023 & & Dallam & 48111 \\
\hline & Cimarron* & 40025 & & Fannin & 48147 \\
\hline & Cotton* & 40033 & & Grayson & 48181 \\
\hline & Craig & 40035 & & Hansford & 48195 \\
\hline & Delaware & 40041 & & Hardeman & 48197 \\
\hline & Ellis* & 40045 & & Hemphill & 48211 \\
\hline & Grant & 40053 & & Lamar & 48277 \\
\hline & Harmon* & 40057 & & Lipscomb & 48295 \\
\hline & Harper & 40059 & & Mantague & 48337 \\
\hline & Jackson* & 40065 & & Ochiltree & 48357 \\
\hline & Jefferson* & 40067 & & Red River & 48387 \\
\hline & Kay & 40071 & & Sherman & 48421 \\
\hline & Le Flore & 40079 & & Wheeler & 48483 \\
\hline & Love* & 40085 & & Wichita & 48485 \\
\hline & Marshall* & 40095 & & Wilbarger & 48487 \\
\hline & McCurtain* & 40089 & \multirow[t]{14}{*}{ Kansas } & Barber & 20007 \\
\hline & Nowata & 40105 & & Chautauqua & 20019 \\
\hline & Osage & 40113 & & Cherokee & 20021 \\
\hline & Ottawa & 40115 & & Clark & 20025 \\
\hline & Roger Mills* & 40129 & & Comanche & 20033 \\
\hline & Sequoyah & 40135 & & Cowley & 20035 \\
\hline & Texas* & 40139 & & Harper & 20077 \\
\hline & Tillman* & 40141 & & Labette & 20099 \\
\hline & Washington & 40147 & & Meade & 20119 \\
\hline & Woods & 40151 & & Montgomery & 20125 \\
\hline \multirow[t]{8}{*}{ Arkansas } & Benton & 05007 & & Morton & 20129 \\
\hline & Crawford & 05033 & & Seward & 20175 \\
\hline & Little River & 05081 & & Stevens & 20189 \\
\hline & Polk & 05113 & & Sumner & 20191 \\
\hline & Scott & 05127 & \multirow[t]{2}{*}{ Missouri } & McDonald & 29119 \\
\hline & Sebastian & 05131 & & Newton & 29145 \\
\hline & Sevier & 05133 & $\begin{array}{l}\text { New } \\
\text { Mexico }\end{array}$ & Union & 35059 \\
\hline & Washington & 05143 & Colorado & Baca & 08009 \\
\hline
\end{tabular}

(C) Southern Regional Science Association 2013. 